\title{
Customer Satisfaction with Network Performance of BSNL and AIRTEL Operating In Gwalior Division (M.P.)
}

\author{
${ }^{1}$ Dr. R. C. Upadhyaya, ${ }^{2}$ Vashundhra Sharma \\ ${ }^{1}$ Prof.Commerce Department, GOVT.K.R.G.College, Jiwaji University, Gwalior (M.P.) \\ ${ }^{2}$ P.hd Scholar, Jiwaji University, Gwalior (M.P.)
}

\begin{abstract}
In the today's competitive world communication plays a very important role. Communication has become an integral part of the growth, success and efficiency of any business. This is the technology that gives a person the power to communicate anytime, anywhere. Due to advancement in technology, now communication becomes easy and faster. In this research paper, special emphasis has been laid over the comparative analysis of telecom companies AIRTEL and BSNL by using primary sources of data in Gwalior division of madhyapradesh. For the completion of efficient research work, descriptive and exploratory research design has been used which further conclude that BSNL is having weak Network performance as compared to Airtel . Trends of previous 5 years in Gwalior division have shown that BSNL Company has slowly deteriorated its position.
\end{abstract}

Keywords: Wireline, Wireless, Broadband, DOT, MTNL, VSNL

\section{Introduction:}

The telecom sector reforms were undertaken in three phases. The first phase began in the 80 's, when private manufacturing of customer promise equipment was given a go-ahead in 1984. A proliferation of individual STD/ISD/PCO network also took place throughout the country by way of private individual franchises. Maharashtra Telephone Nigam (MTNL) was created out of the department of telecommunication (DOT) to handle the sectors of Mumbai and Delhi respectively. A high powered telecom commission was set up in 1989. Later Videsh Sanchar Nigam (VSNL) became the international service provider catering to telecom services originating from India. The second phase of reforms commenced in 1991 with the announcement of new economic policy. The government delivered the manufacturer of telecom equipment in 1991. It also ahead up radio services in 1992. In 1994, basic telephony was opened to the private sector by granting operating licenses to six companies. Also part of the second phase was the introduction of the National Telecom Policy 1994. It emphasized universal service and qualitative improvement in telecom services among other objectives. An independent statutory regulatory was established in 1997, Internet services were opened up in 1998.

The third phase \& reforms began with the announcement of the new telecom policy in 1999. The theme of NTP was to usher in full competition through a restricted entry of private players in all service sectors. The policy favored the migration of existing operators from the era of fixed license fee regime to that of revenue sharing. The policy further declined the strengthen of the regulator opening up of international long distance (ILD) and National Long Distance (NLD) services to the private sector and corporation of telecom services. The year 2001 witnessed the entry of private operators in offering basic telephony and NLD services. The telecom sector began witnessing a trend of growth with these reforms basic services were opened for unlimited competition more licenses were issued to the private sector for cellular services. There has also been a considerable increase in the rate of tale density. The telecom sector has thus completely changed both in terms of coverage and efficiency of services. Provision of landlines a demand, digital telephone, exchanges and the acceptability of optic fiber and wireless technology are a few instances of the change that took instances of the change that took place in the industry. Cellular telephone services have achieved great commercial success; because users recognize the mobile telephone access can improve productivity and enhance safety. A new subscriber is opting for cellular services for personal security, safety and convenience. Increase in demand and the poor quality of existing telecommunications landline services. Mobile service providers will be benefited from the research, the ways to improve their quality of service and to support more users in their system. The present study has been made to identity the customer's attitude towards cell phones ,telephones,broadband services of BSNL and AIRTEL in Gwalior Division. Many private operators have entered in to the cellular segment to provide services. It has brought heavy competition in to the market. They have to find out the customers attitudes towards this service which could be useful to formulate new strategies policy and market their services in a better way. 


\section{Research Methology:}

Primary data was collected through observation, questionnaires and interviews. Along with Filling up of questionnaire interviews in local language with customer was done. The data is selected as a major primary data collection method, since the aim of the study is the customers perceived service quality and how it is related to customer satisfaction our main focus is thus the customer.

\section{Definition of key terms:-}

Wireline service - These are the telephone services that are provided by various service providers for home / office installations. These telephone connections are connected by a copper wire.

Wireless service - This service encompasses the services based on both GSM and CDMA network technologies. These are typically known as mobile services.

Broadband service - Broadband' is defined in the Broadband Policy 2004 as "An always on data connection that is able to support interactive services including Internet access and has the capability of the minimum download speed of 256 kilo bits per second (kbps) to an individual subscriber from the Point of Presence (POP) of the service provider intending to provide Broadband service where multiple such individual Broadband connections are aggregated and the subscriber is able to access these interactive services including the Internet through this POP. The 2 interactive services will exclude any services for which a separate license is specifically required, for example, real-time voice transmission, except to the extent that it is presently permitted under ISP license with Internet Telephony".

\section{Data Analysis:}

The study was conducted in two modules. The first module (subjective survey) was undertaken to gauge the subscriber feedback on Network Performance by way of a large sample based field survey. The second module (objective assessment) involved auditing of the QoS monitoring records of telecom operators. To gauge the level of satisfaction of subscribers with the Network Performance provided by the service providers, interviews across a large sample of subscribers for Basic (Wireline), Cellular Mobile (Wireless) and broadband services were conducted. The sample survey was conducted to ensure spread across operators on the basis of their subscriber size and the type of circle in which we are conducting the interviews. The satisfaction level of subscribers was collected on a four-point scale of "Very satisfied", "satisfied", "dissatisfied" and "very dissatisfied". data of table is shown in percentage.

\section{TABLE-1}

\begin{tabular}{|c|c|c|c|c|c|c|c|c|c|c|}
\hline \multicolumn{11}{|c|}{ WIRELESS SERVICE } \\
\hline & \multicolumn{2}{|c|}{2008} & \multicolumn{2}{|c|}{2009} & \multicolumn{2}{|c|}{2010} & \multicolumn{2}{|c|}{2011} & \multicolumn{2}{|c|}{2012} \\
\hline & BSNL & AIRTEL & BSNL & AIRTEL & BSNL & AIRTEL & BSNL & AIRTEL & BSNL & AIRTEL \\
\hline $\begin{array}{c}\text { Very } \\
\text { Satisfied }\end{array}$ & 7 & 19 & 9 & 18 & 8 & 21 & 5 & 22 & 7 & 14 \\
\hline Satisfied & 38 & 58 & 36 & 62 & 35 & 58 & 44 & 54 & 49 & 71 \\
\hline Dissatisfied & 42 & 17 & 36 & 14 & 38 & 14 & 34 & 17 & 32 & 12 \\
\hline $\begin{array}{c}\text { Very } \\
\text { Dissatisfied }\end{array}$ & 13 & 6 & 19 & 6 & 19 & 7 & 17 & 7 & 12 & 3 \\
\hline
\end{tabular}

Table -1 is showing Customer's Satisfaction with Network Performance of BSNL and AIRTEL in wireless service. Last five years data is summarize in table.

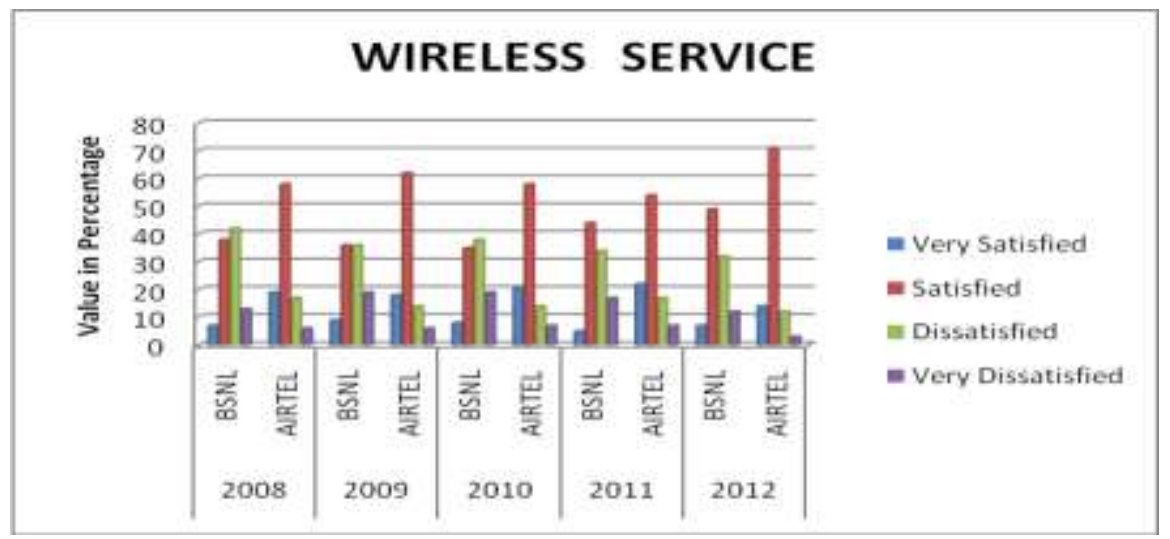

Figure-1

Figure-1 is showing Customer's Satisfaction with Network Performance of BSNL and AIRTEL in wireless service. 
Customer Satisfaction With Network Performance Of BSNL and AIRTEL Operating in Gwalior TABLE-2

\begin{tabular}{|c|c|c|c|c|c|c|c|c|c|c|}
\hline \multicolumn{11}{|c|}{ BROADBAND SERVICE } \\
\hline & \multicolumn{2}{|c|}{2008} & \multicolumn{2}{|c|}{2009} & \multicolumn{2}{|c|}{2010} & \multicolumn{2}{|c|}{2011} & \multicolumn{2}{|c|}{2012} \\
\hline & BSNL & AIRTEL & BSNL & AIRTEL & BSNL & AIRTEL & BSNL & AIRTEL & BSNL & AIRTEL \\
\hline Very & & & & & & & & & & \\
\hline Satisfied & 17 & 21 & 23 & 22 & 21 & 19 & 24 & 23 & 26 & 19 \\
\hline Satisfied & 67 & 68 & 69 & 67 & 76 & 77 & 73 & 74 & 72 & 78 \\
\hline $\begin{array}{c}\text { Dissatisfie } \\
\mathrm{d} \\
\end{array}$ & 9 & 6 & 6 & 7 & 2 & 2 & 2 & 3 & 1 & 2 \\
\hline $\begin{array}{c}\text { Very } \\
\text { Dissatisfie } \\
\text { d }\end{array}$ & 7 & 5 & 2 & 4 & 1 & 2 & 1 & 0 & 1 & 1 \\
\hline
\end{tabular}

Table -2 is showing Customer's Satisfaction with Network Performance of BSNL and AIRTEL in broadband service. Last five years data is summarize in table.

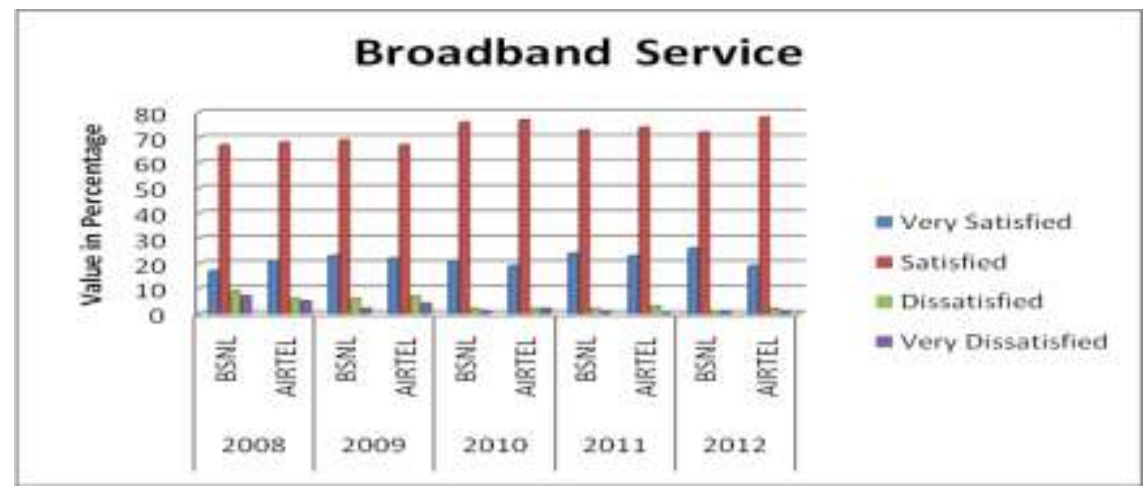

Figure-2

Figure-2 is showing Customer's Satisfaction with Network Performance of BSNL and AIRTEL in broadband service.

TABLE-3

\begin{tabular}{|c|c|c|c|c|c|c|c|c|c|c|}
\hline \multicolumn{11}{|c|}{ WIRELINE SERVICE } \\
\hline & \multicolumn{2}{|c|}{2008} & \multicolumn{2}{|c|}{2009} & \multicolumn{2}{|c|}{2010} & \multicolumn{2}{|c|}{2011} & \multicolumn{2}{|c|}{2012} \\
\hline & BSNL & AIRTEL & BSNL & AIRTEL & BSNL & AIRTEL & BSNL & AIRTEL & BSNL & AIRTEL \\
\hline $\begin{array}{c}\text { Very } \\
\text { Satisfied }\end{array}$ & 5 & 13 & 9 & 15 & 12 & 13 & 9 & 7 & 7 & 12 \\
\hline Satisfied & 58 & 67 & 53 & 64 & 71 & 73 & 77 & 79 & 69 & 78 \\
\hline $\begin{array}{c}\text { Dissatisfie } \\
\mathrm{d}\end{array}$ & 23 & 11 & 25 & 12 & 11 & 9 & 11 & 9 & 17 & 7 \\
\hline $\begin{array}{c}\text { Very } \\
\text { Dissatisfie } \\
\mathrm{d}\end{array}$ & 14 & 9 & 13 & 9 & 6 & 5 & 3 & 5 & 7 & 3 \\
\hline
\end{tabular}

Table -3 is showing Customer's Satisfaction with Network Performance of BSNL and AIRTEL in wireline service. Last five years data is summarize in table.

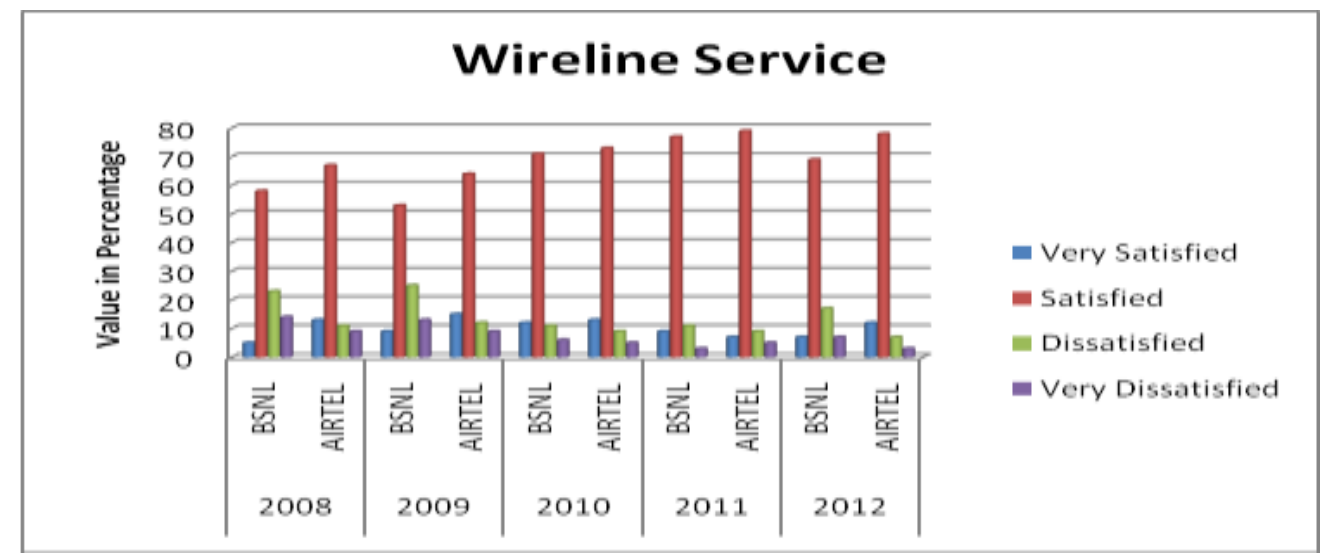

Figure-3

Figure-3 is showing Customer's Satisfaction with Network Performance of BSNL and AIRTEL in wireline service. 


\section{Conclusion:-}

This paper presenting customer satisfaction in Gwalior division with some QoS parameter. This paper is based on a survey which is done in Gwalior division on BSNL and AIRTEL service providers. here we prepare questionnaire for wireline, wireless and broadband customer separately which includes questions regarding Network Performance, Reliability and Availability . On the basis of data that are filled by customers we analyzed performance of BSNL and AIRTEL on Customers satisfaction with Network Performance. after analysis of performance we found that customers are very satisfy with the services which are providing by AIRTEL. customers are not satisfy with the services that are providing by BSNL.in some case there is need to improve the services of BSNL otherwise in future due to competitive environment survival of BSNL is not possible.

\section{Future Scope:}

This paper is limited to survey the customer satisfaction in Gwalior division which include Gwalior ,Datia, Shivpuri ,Guna, and Ashoknagar. one can go to survey the same for different division of Madhya Pradesh. this paper is basically focus comparisons between BSNL and AIRTEL service providers, one can go to do same survey with different service providers like reliance,idea,aircel,vodafone etc.it can be done in rural and urban area separately.

\section{References:}

[1] Dr. Sarika .R. Lohana (2012)," Customer Respond And Satisfaction Against Marketing Strategies Of Selected Cellular Service Providers In Nanded City" International Journal of Multidisciplinary Management Studies, Vol.2 Issue 3, March 2012, ISSN 2249 8834.

[2] ESHA SHARMA “ COMPARISON OF BSNL WITH OTHER TELECOM INDUSTRIES” APJRBM Volume 2, Issue 1 (JANUARY 2011) ISSN 2229-4104

[3] Malik V. (2010): "The New Marketing Border" The Journal of AIMA, Vol. 49, Issue 10, pp.82-84.

[4] Internationalisation in the telecommunications services industry: Literature review and research agendaOriginal Research Article telecommunications Policy, Volume 32, Issue 8, September 2008, Pages 531-544 Nejc M. Jakopin

[5] Business customer's satisfaction What happens when suppliers downsize? Original Research Article Industrial Marketing Management, Volume38,Issue3, April2009, Pages283-299Jeffrey E. Lewin

[6] Mobile phone feature preferences, customer satisfaction and repurchase intent among male users Original Research Article Australasian Marketing Journal (AMJ), Volume 19, Issue 4, November 2011, Pages 238-246 Matti Haverila 